\title{
Production, characterization, and antitumor efficiency of L-glutaminase from halophilic bacteria
}

\author{
Eman Zakaria Gomaa*
}

\begin{abstract}
Background: Halophiles are an excellent source of enzymes that are not only salt stable, but also can withstand and carry out reaction efficiently under extreme conditions. L-glutaminase has attracted much attention with respect to proposed applications in several fields such as pharmaceuticals and food industries. The aim of the present study was to investigate the anticancer activity of L-glutaminase produced by halophilic bacteria. Various halophilic bacterial strains were screened for extracellular L-glutaminase production. An attempt was made to study the optimization, purification, and characterization of L-glutaminase from Bacillus sp. DV2-37. The antitumor activity of the produced enzyme was also investigated.

Results: The potentiality of 15 halophilic bacterial strains isolated from the marine environment that produced extracellular L-glutaminase was investigated. Bacillus sp. DV2-37 was selected as the most potent strain and optimized for enzyme production. The optimization of fermentation process revealed that the highest enzyme activity $(47.12 \mathrm{U} / \mathrm{ml})$ was observed in a medium supplemented with $1 \%(\mathrm{w} / \mathrm{v})$ glucose as a carbon source, $1 \%(\mathrm{w} / \mathrm{v})$ peptone as a nitrogen source, $5 \%(\mathrm{w} / \mathrm{v}) \mathrm{NaCl}$, the initial pH was 7.0 , at $37^{\circ} \mathrm{C}$, using $20 \%(\mathrm{v} / \mathrm{v})$ inoculum size after $96 \mathrm{~h}$ of incubation. The produced crude enzyme was partially purified by ammonium sulfate precipitation and dialysis. Of the various parameters tested, $\mathrm{pH} 7,40^{\circ} \mathrm{C}$, and $5 \% \mathrm{NaCl}$ were found to be the best for L-glutaminase activity. The enzyme also exhibited high salt and temperature stability. The antitumor effect against human breast (MCF-7), hepatocellular (HepG-2), and colon (HCT-116) carcinoma cell lines revealed that L-glutaminase produced by Bacillus sp. DV2-37 showed potent cytotoxic activity of all the tested cell lines in a dose-dependent manner with an $I C_{50}$ value of $3.5,3.4$, and $3.8 \mu \mathrm{g} / \mathrm{ml}$, respectively.
\end{abstract}

Conclusions: The present study proved that L-glutaminase produced by marine bacteria holds proper features and it has a high potential to be useful for many therapeutic applications.

Keywords: L-glutaminase, Halophilic bacteria, Optimization, Characterization, Antitumor agent

\section{Background}

L-glutaminase (L-glutamine amidohydrolase EC 3.5.1.2) catalyzes the hydrolytic degradation of L-glutamine to L-glutamic acid and ammonia (Nandakumar et al. 2003). L-glutaminase is an amide enzyme that has a significant contributory role in cellular nitrogen metabolism in all

*Correspondence: emann7778@yahoo.com

Department of Biological and Geological Sciences, Faculty of Education, Ain Shams University, Cairo, Egypt living cells (Kiruthika and Saraswathy 2013). In food industry, L-glutaminase is used as a flavor and aroma enhancing agent (Rajeev and Chanrdasekaran 2003). L-glutaminase is generally regarded as a key enzyme that controls the delicious taste of fermented foods such as soy sauce (Renu et al. 2003). L-glutaminase has been considered to play a significant role in enzyme therapy for cancer treatment, especially in acute lymphocytic leukemia. It was also found to be effective against human immunodeficiency virus (HIV) (Zhao et al. 2004). 
Another important application of L-glutaminase is in biosensors for monitoring glutamine levels in mammalian and hybridoma cell cultures without the need for separate measurement of glutamic acid (Padma and Singhal 2007).

L-glutaminase enzyme is ubiquitous in nature and reported in animals, plants, bacteria, actinomycetes, yeast, and fungi (Ardawi and Newsholme 1983; Binod et al. 2017). Attempts are being made to replace enzymes, which traditionally have been isolated from animal tissues and plants to enzymes from microorganisms because microbial enzymes are cheaper to produce, more predictable, controlled, and reliable (Teja et al. 2014; Aishwariyaa et al. 2020). Many bacteria synthesize extracellular and intracellular glutaminases such as Bacillus sp., Pseudomonas, Actinobacterium sp, and E. coli. (Amobonye et al. 2019). The focal sources of fungal glutaminases are Aspergillus sp. and Trichoderma sp. (Singh and Banik 2013).

Reports showed that the majority of microbes producing L-glutaminase have been isolated from soil and aquatic (marine) environment (Iyer and Singhal 2010; Yulianti et al. 2012). L-glutaminases produced by terrestrial microorganisms have been reported to have some disadvantages such as unstable in extreme conditions, incompatible with human blood, and may induce a lot of side effects to patients. Thus, there is a great urgency to investigate other enzymatic sources (Sabu 2003).

Halophilic microorganisms are a potential source of extremozymes called halozymes which are capable of functioning under high concentrations of salt, a wide range of $\mathrm{pH}$ values, and temperatures (Balagurunathan et al. 2010). Furthermore, over the past few decades, Several efforts have been made to discover the potential abilities of these extremophiles and using them efficiently for therapeutic purposes. The important features of these enzymes that distinguish them from all other types of drugs are high affinity, specificity, and catalytic efficiency (Aishwariyaa et al. 2020). Hence, there is an increasing interest in the identification of marine microbial strains and developing the practical bio-processing technique to improve their productivity for therapeutic purpose.

\section{Methods}

\section{Enrichment and screening of L-glutaminase isolates}

Halophilic bacterial strains were isolated from water samples collected from the mangrove region on the western coast of the Red Sea, Egypt. About $1.0 \mathrm{ml}$ of seawater was serially diluted in sterilized distilled water up to $10^{6}$ dilutions. Hundred microliters of aliquot from $10^{3}$ to $10^{6}$ dilutions were spread on minimal glutamine agar (MGA) medium using the sterile L-rod. The constituents of MGA (g/l) include $1.0 \mathrm{NaCl}, 0.5 \mathrm{KCl} ; 0.5 \mathrm{MgSO}_{4} ; 1.0 \mathrm{KH}_{2} \mathrm{PO}_{4}$;
0.1 $\mathrm{FeSO}_{4} ; 0.1 \mathrm{ZnSO}_{4} ; 10$ glutamine, 0.12 Phenol red and cycloheximide $(20 \mu \mathrm{g} / \mathrm{ml})$ (Hymavathi et al. 2009). L-glutamine acts as the sole carbon and nitrogen source. Phenol red acts as a $\mathrm{pH}$ indicator. Cycloheximide retards the fungal growth. The plating was done in triplicate and all the plates were incubated at $37^{\circ} \mathrm{C}$ for $48 \mathrm{~h}$. Only the bacteria which synthesize L-glutaminase can grow in MGA medium and the extracellular production of L-glutaminse was detected. The formation of a pink zone around colonies indicated a positive response due to accumulation of ammonia, which has resulted in a change in $\mathrm{pH}$ indicator color from yellow to pink due to the increase in $\mathrm{pH}$ value which is caused by L-glutamine use.

The secondary screening for the highly producer isolates was done by culturing the positive strains for enzyme production in liquid minimal glutamine medium. All the flasks were incubated at $37^{\circ} \mathrm{C}$ for $72 \mathrm{~h}$ in a rotary shaker at $150 \times g$. After centrifugation of the cultures by using a cooling centrifuge at $10,000 \times g$ for $30 \mathrm{~min}$ at $4{ }^{\circ} \mathrm{C}$, the optical density (OD) of each supernatant was measured at $540 \mathrm{~nm}$ using a visible spectrophotometer (Abd-Alla et al. 2013). A culture, giving the highest L-glutaminase production was used further for L-glutaminase production. Regular subculturing of the selected isolate was performed at an interval of every 4 weeks and preserved at refrigerated conditions as slant culture.

\section{Identification of bacterial stain}

Bacterial isolate showing the highest L-glutaminase production was tested for species identity using the $16 \mathrm{~S}$ rRNA sequencing method (Rochelle et al. 1995). The gene sequencing was done at Macrogen (South Korea). DNA sequences were aligned using Gene Mapper v4.1 \& Data Collection v 3.1 Communication Patch1. To extract the genomic DNA, bacterial colonies are picked with a sterilized toothpick and suspended in $0.5 \mathrm{ml}$ of sterilized saline, then centrifuged at $10,000 \times g$ for $10 \mathrm{~min}$. After removal of supernatant, the pellet was suspended in $0.5 \mathrm{ml}$ of Insta Gene Matrix (Bio-Rad, USA), incubated at $56{ }^{\circ} \mathrm{C}$ for $30 \mathrm{~min}$, and then heated to $100{ }^{\circ} \mathrm{C}$ for $10 \mathrm{~min}$. After heating, the supernatant can be used for the PCR reaction. Bacterial $16 \mathrm{~S}$ rRNAs were amplified using the following universal bacterial 16S rRNA primers: forward primer 27F (5'-AGAGTTTGATCMTGGCTCAG-3') and reverse primer $1792 \mathrm{R}$ (5'-TACGGYTACCTTGTTACG ACTT-3'). The polymerase chain reaction was performed using kits with Ampli Taq DNA polymerase (FSenzyme; Applied Biosystems). One microlitre of template DNA was added to $20 \mu \mathrm{l}$ of PCR reaction solution. Amplification was performed using 35 cycles at $94{ }^{\circ} \mathrm{C}$ for $45 \mathrm{~s}$, $55{ }^{\circ} \mathrm{C}$ for $60 \mathrm{~s}$, and $72{ }^{\circ} \mathrm{C}$ for $60 \mathrm{~s}$. The PCR amplicon was purified using a Montage PCR clean-up kit (Millipore). The purified PCR products of approximately $1400 \mathrm{bp}$ 
were sequenced using 2 primers $518 \mathrm{~F}$ ( $5^{\prime}$-CCA GCA GCC GCG GTA ATA Cg-3') and 800R (5'-TAC CAG GGT ATC TAA TCC-3'). Sequencing was performed using a Big Dye terminator cycle sequencing kit (Applied Biosystems, USA). Sequencing products were resolved on an Applied Biosystems model 3730XL automated DNA sequencing system (Applied Biosystems, USA). Sequence analysis was performed with sequences in the National Center for Biotechnology Information (NCBI), USA database using Basic Local Alignment Search Tool for Nucleotides (BLASTN) (Altschul et al. 1997).

\section{Inoculum preparation}

The inoculum of the tested bacterial strain was prepared in $250 \mathrm{ml}$ Erlenmeyer flasks containing $50 \mathrm{ml}$ of nutrient broth liquid medium ( $\mathrm{pH}$ 7). Prepared medium was autoclaved and then inoculated with a loopful of culture from $24 \mathrm{~h}$ old nutrient agar slant. The inoculated flasks were kept on a shaker at $150 \times g$ for $24 \mathrm{~h}$ and used as the inoculum.

\section{Production and extraction of L-glutaminase}

Five $\mathrm{ml}$ of the prepared inoculum was transferred aseptically to $45 \mathrm{ml}$ of minimal glutamine (MG) production medium. All the flasks were incubated at $37^{\circ} \mathrm{C}$ in a rotary shaker at $150 \times g$ for $72 \mathrm{~h}$. After every $24 \mathrm{~h}, 10 \mathrm{ml}$ of sample was removed aseptically and centrifuged using cooling centrifuge at $10,000 \times g$ for $30 \mathrm{~min}$ at $4{ }^{\circ} \mathrm{C}$. The clear supernatant was used for enzyme estimation (Chanakya et al. 2010).

\section{L-glutaminase assay}

Assay of L-glutaminase was carried out as described by Chanakya et al. (2010) utilizing L-glutamine as a substrate and the released ammonia was measured using Nessler reagent. Briefly, $0.5 \mathrm{ml}$ of $0.04 \mathrm{M}$ glutamine was taken in a test tube, to which $0.5 \mathrm{ml}$ of $0.05 \mathrm{M}$ buffer (Tris $\mathrm{HCl}, \mathrm{pH}$ 7.2 ), $0.5 \mathrm{ml}$ of enzyme, and $0.5 \mathrm{ml}$ of distilled water was added to make up the volume up to $2.0 \mathrm{ml}$, the reaction mixture was incubated at $37^{\circ} \mathrm{C}$ for $30 \mathrm{~min}$. After incubation, the reaction was stopped by adding $0.5 \mathrm{ml}$ of $1.5 \mathrm{M}$ TCA (Trichloro-acetic acid). The precipitated proteins were removed by centrifugation $(1000 \times g$ for $20 \mathrm{~min})$. The blank was prepared similarly without adding enzyme preparation. $0.1 \mathrm{ml}$ was taken from the above-mentioned reaction mixture and added to $3.7 \mathrm{ml}$ distilled water and to that $0.2 \mathrm{ml}$ of Nessler's reagent was added, incubated for $10 \mathrm{~min}$, and the absorbance (OD) was measured at $450 \mathrm{~nm}$ using a UV-visible spectrophotometer. Then a standard curve was plotted using ammonium sulfate as the standard for estimation of ammonia liberated. One unit of L-glutaminase is the amount of enzyme which liberates $1 \mu \mathrm{mol}$ of ammonia per minute per $\mathrm{ml}(\mu \mathrm{mole} / \mathrm{ml} /$ min) under optimal assay conditions. Assays were done in triplicate, and the mean enzyme activity was expressed as unit per $\mathrm{ml}(\mathrm{U} / \mathrm{ml})$.

\section{Protein estimation}

Protein content in the crude enzyme source was estimated by Lowry's method (Lowry et al. 1951) using bovine serum albumin as the standard, and the values were expressed as $\mathrm{mg} / \mathrm{ml}$.

\section{Optimization of L-glutaminase production}

Various process parameters that enhance the yield of L-glutaminase by Bacillus sp. DV2-37 was investigated. The effect of incorporation of additional carbon sources (glucose, fructose, sucrose, dextrose, maltose, galactose, lactose, mannitol and soluble starch at $1 \% \mathrm{w} / \mathrm{v}$ ) and nitrogen sources (peptone, yeast extract, beef extract, malt extract, urea, ammonium chloride, ammonium sulfate, ammonium nitrate, and sodium nitrate and amino acids (L-glutaminase, L-asparagine, L-glutamic acid, L-arginine, $\mathrm{L}$-methionine, $\mathrm{L}$-proline, $\mathrm{L}$-lysine at $1 \% \mathrm{w} / \mathrm{v}$ ) were investigated. Moreover, the effect of different concentrations of sodium chloride (1-9\%), initial $\mathrm{pH}$ values (5-9), incubation temperatures $\left(25-40{ }^{\circ} \mathrm{C}\right)$, inoculum concentrations (5-25\%), and incubation periods $(24-120 \mathrm{~h})$ was studied. During this optimization process, once a particular parameter was optimized, the same optimum condition of that specific parameter was employed in the subsequent studies wherein another parameter is to be optimized. All the extracts obtained from above parameters were studied for L-glutaminase activity. The experiments were conducted in triplicate, and the mean values were reported.

\section{Partial purification of L-glutaminase}

The purification was carried out using $500 \mathrm{ml}$ of crude enzyme extract. Finely powdered ammonium sulphate was slowly added into cell-free supernatant (crude enzyme) so as to reach $40 \%$ saturation. The whole content was stirred at $4{ }^{\circ} \mathrm{C}$ using a magnetic stirrer. The precipitated crude enzyme was removed by centrifugation at $10,000 \times g$ at $4{ }^{\circ} \mathrm{C}$ for $20 \mathrm{~min}$. Fresh ammonium sulfate was added to the supernatant to increase the saturation to $50 \%$. The obtained precipitate was re-suspended in a minimal volume of $0.01 \mathrm{M}$ phosphate buffer $(\mathrm{pH} 8)$. Precipitated protein was removed by centrifugation as described earlier. Once again the fresh ammonium sulfate was added to the cell free supernatant to increase the concentration to $80 \%$. The obtained enzyme precipitate was re-suspended in a minimal volume of $0.01 \mathrm{M}$ phosphate buffer $(\mathrm{pH} 8)$ and precipitated protein was recovered by centrifugation (Aly et al. 2017). The enzyme precipitate obtained after ammonium sulphate 
precipitation was dialyzed against $0.01 \mathrm{M}$ phosphate buffer ( $\mathrm{pH} 8$ ) for $24 \mathrm{~h}$ at $4{ }^{\circ} \mathrm{C}$ with continuous stirring and occasional changes of the buffers. The dialyzed fractions were collected and freeze-dried, and the lyophilized enzyme was used for the following assays.

\section{Enzyme characteristics The effect of $\mathrm{pH}$ on enzyme activity and stability}

The effect of $\mathrm{pH}$ on L-glutaminase activity was determined by assaying the enzyme activity at different $\mathrm{pH}$ values ranging from 4.0 to 10.0 as described above. The used buffers were as follows: $50 \mathrm{mM}$ of citrate-phosphate buffer ( $\mathrm{pH} 4.0-6.0$ ), phosphate buffer ( $\mathrm{pH} 7.0-8.0$ ), and glycine- $\mathrm{NaOH}$ buffer ( $\mathrm{pH} 9.0-10.0)$. The $\mathrm{pH}$ stability of the enzyme was investigated in the same $\mathrm{pH}$ range and incubated for $1 \mathrm{~h}$. Afterward, aliquots of the mixtures were taken to measure the residual $\mathrm{L}$-glutaminase activity (\%) with respect to the control, under standard assay conditions (Jeong et al. 2010).

\section{The effect of temperature on enzyme activity and stability}

The effect of temperature on L-glutaminase activity was determined by incubating the reaction mixture at optimum $\mathrm{pH}$ value under different temperature ranging from $\left(30-80{ }^{\circ} \mathrm{C}\right)$. In order to determine the thermostability of the enzyme, experiments were conducted by measuring the residual activity after incubation in the same temperatures range for $1 \mathrm{~h}$ under standard assay conditions (Jeong et al. 2010).

\section{The effect of different $\mathrm{NaCl}$ concentrations}

The effect of different $\mathrm{NaCl}$ concentrations on L-glutaminase activity was examined by incubating $100 \mu \mathrm{l}$ of partial purified enzyme with $100 \mu \mathrm{l}$ of each concentration (1, 3, 5, 7, 9 and 12\%) and the activity was then measured by a standard enzyme assay. In order to determine the stability of the enzyme, experiments were conducted by measuring the residual activity after incubation in the same concentrations range for $1 \mathrm{~h}$ under standard assay conditions (Jeong et al. 2010).

\section{Anticancer activity}

The anticancer activity of the produced L-glutaminase was studied against human breast (MCF-7), hepatocellular (HepG-2), and colon (HCT-116) carcinoma cell lines besides one normal cell line, namely, human epithelial retina cells (RPE- 1), which were obtained from the American Type Culture Collection (ATCC, Manassas, VA, USA). The cells were propagated in 24-well plate (BD Biosciences, San Jose, CA, USA) in Dulbecco's modified Eagle's medium (DMEM) supplemented with $10 \%$ heatinactivated fetal bovine serum, $1 \%$ L-glutamine, HEPES buffer, and $50 \mu \mathrm{g} / \mathrm{ml}$ gentamycin. The cell suspension $\left(10^{5} \mathrm{cells} / \mathrm{ml}\right)$ was seeded in every well and incubated at $37{ }^{\circ} \mathrm{C}$ for $48 \mathrm{~h}$ in $5 \% \mathrm{CO}_{2}$ for the formation of a confluent monolayer. The cell viability was measured using MTT assay (Renugadevi and Venus 2012). The MTT assay is based on the reduction of yellow 2,5-diphenyl tetrazolium bromide to purple formazan by actively growing cells. The monolayer of cells in 24-well plates was incubated alone or with an enzyme at different concentration $(50,25,12.5,6.25,3.125$, and $1.56 \mu \mathrm{g} / \mathrm{ml})$ for $48 \mathrm{~h}$. After incubation, $20 \mu \mathrm{l}$ MTT stock solution ( $5 \mathrm{mg} /$ $\mathrm{ml}$ in phosphate-buffered saline or PBS, $\mathrm{pH} 7.5$, filtered through $0.22-\mu \mathrm{m}$ cellulose acetate filter; Sigma, St. Louis) was added to each well, incubated for $4 \mathrm{~h}$ at $37^{\circ} \mathrm{C}$ then the solution was decanted. To stop succinate-tetrazolium reductase activity and solubilize formazan crystals, $100 \mu \mathrm{l}$ of propanol was then added to each well. The viable cells yield was determined by a colorimetric method. The percentage of viable cells was calculated as follows: Cell proliferation $(\%)=(\mathrm{OD}$ experimental group $/ \mathrm{OD}$ control group) $\times 100$. The $50 \%$ inhibitory concentration $\left(\mathrm{IC}_{50}\right)$, enzyme concentration causing $50 \%$ inhibition of intact cells was calculated from the graph plotting percentage of cell viability against enzyme concentration. The lower the $\mathrm{IC}_{50}$ value indicates high antitumor capacity.

\section{Statistical analysis}

Data were expressed as means $\pm \mathrm{SD}$. The mean values were calculated based on the data taken from at least three independent experiments $(n=3)$. Statistical analysis was performed by using the Student's t-test. Differences were considered significant at $P<0.05$.

\section{Results}

In the present study, totally, 25 morphologically different bacterial isolates were selected from the sediment samples collected from marine ecosystems. Of these, 15 bacterial isolates produced measurable pink color zone around the colony on minimal glutamine agar (MGA) medium ranged from 7.5 to $18 \mathrm{~mm}$ that was proportional to their ability to produce L-glutaminase. The quantitative screening for L-glutaminase production was evaluated using submerged fermentation revealed that these isolates produced L-glutaminase with a range activity of $0.9-5.16 \mathrm{U} / \mathrm{ml}$. The isolate showing the highest production of L-glutaminase $(5.16 \mathrm{U} / \mathrm{ml})$ was selected for further study. To confirm the identification of the selected isolate, 16SrRNA gene sequence analysis was performed. The sequence alignment using BLASTN software for the comparison of up to $1500 \mathrm{bp}$ indicated that the $16 \mathrm{~S}$ rRNA gene sequence of the selected strain exhibits a high homology (98\%) with that of Bacillus sp. DV2-37. 


\section{Optimization of L-glutaminase production The effect of carbon sources}

The results cited in Table 1 showed that incorporation of additional carbon sources enhanced the enzyme yield from 5.16 to $18.13 \mathrm{U} / \mathrm{ml}$ by the tested marine bacterium. Among the various sugars tested for their effects on the L-glutaminase production, glucose was found to be the best carbon source, yielding maximum L-glutaminase production $(18.13 \mathrm{U} / \mathrm{ml})$ followed by maltose $(17.09 \mathrm{U} /$ $\mathrm{ml})$.

\section{The effect of nitrogen sources}

The results of the effect of the addition of different inorganic and organic nitrogen sources on enzyme production level revealed that peptone enhanced the enzyme yield from 18.85 to $36.08 \mathrm{U} / \mathrm{ml}$. Among the different amino acids tested, L-glutamine was observed to enhance L-glutaminase synthesis $(36.12 \mathrm{U} / \mathrm{ml})$ (Table 1$)$.

\section{The effect of sodium chloride concentrations}

The results cited in Table 1 showed that the yield of L-glutaminase was increased with increasing $\mathrm{NaCl}$ concentration up to $5 \%$ as maximum as $40.06 \mathrm{U} / \mathrm{ml}$ and it was low in $1 \%$ and $3 \%$ of $\mathrm{NaCl}$ concentrations. Yield was decreased, when the concentration was increased above $5 \%$. Hence, $5 \%$ of $\mathrm{NaCl}$ concentration was the optimum for the production of L-glutaminase from Bacillus sp. DV2-37.

\section{The effect of initial $\mathrm{pH}$}

In the present study, the optimum L-glutaminase production reached $40.32 \mathrm{U} / \mathrm{ml}$ was recorded at $\mathrm{pH} 7.0$ and any further alteration either increase or decrease of the

Table 1 Effect of various nutritional and environmental factors on L-glutaminase production by Bacillus sp. DV2-37. Data represent the mean of 3 different readings \pm standard deviation

\begin{tabular}{|c|c|c|c|}
\hline Factors & Enzyme activity (U/ml) & Factors & Enzyme activity (U/ml) \\
\hline Carbon source (1\% w/v) & & $\mathrm{NaCl}(\%)$ & \\
\hline Control & $5.16 \pm 0.2$ & 1 & $36.55 \pm 1.5$ \\
\hline glucose & $18.13 \pm 1.5$ & 3 & $38.00 \pm 2.4$ \\
\hline Fructose & $7.11 \pm 0.65$ & 5 & $40.06 \pm 5.6$ \\
\hline Sucrose & $15.10 \pm 0.66$ & 7 & $36.70 \pm 2.06$ \\
\hline Dextrose & $16.9 \pm 0.85$ & 9 & $29.12 \pm 1.56$ \\
\hline Maltose & $17.09 \pm 0.95$ & $\mathrm{pH}$ & \\
\hline Galactose & $10.08 \pm 0.30$ & 5 & $23.58 \pm 5.4$ \\
\hline Lactose & $13.92 \pm 1.0$ & 6 & $30.92 \pm 4.2$ \\
\hline Mannitol & $8.20 \pm 0.98$ & 7 & $40.32 \pm 1.2$ \\
\hline Starch & $6.07 \pm 0.20$ & 8 & $36.47 \pm 1.5$ \\
\hline Nitrogen source $(1 \% \mathrm{w} / \mathrm{v})$ & & 9 & $34.10 \pm 2.3$ \\
\hline Control & $18.85 \pm 2.30$ & Temperature & \\
\hline Peptone & $36.08 \pm 1.45$ & 25 & $24.48 \pm 1.90$ \\
\hline Yeast extract & $32.90 \pm 1.63$ & 30 & $32.33 \pm 1.04$ \\
\hline Beef extract & $27.25 \pm 2.10$ & 35 & $38.56 \pm 2.20$ \\
\hline Malt extract & $29.00 \pm 1.25$ & 37 & $40.80 \pm 1.4$ \\
\hline Urea & $18.95 \pm 1.12$ & 40 & $29.00 \pm 1.0$ \\
\hline $\mathrm{NH} 4 \mathrm{Cl}$ & $25.30 \pm 1.65$ & Inoculum size (\%) & \\
\hline $\mathrm{NH} 4 \mathrm{SO} 4$ & $23.40 \pm 1.44$ & 5 & $33.00 \pm 1.25$ \\
\hline $\mathrm{NH} 4 \mathrm{NO} 3$ & $20.80 \pm 3.12$ & 10 & $40.84 \pm 1.12$ \\
\hline $\mathrm{NaNO} 3$ & $19.11 \pm 2.54$ & 15 & $42.55 \pm 5.62$ \\
\hline Amino acids (1\% w/v) & & 20 & $45.05 \pm 2.58$ \\
\hline L-glutamine & $36.12 \pm 1.10$ & 25 & $35.25 \pm 4.20$ \\
\hline L-asparagine & $28.86 \pm 0.12$ & Incubation time (h) & \\
\hline L-glutamic acid & $12.60 \pm 2.14$ & 24 & $20.08 \pm 2.0$ \\
\hline L-arginine & $18.01 \pm 0.02$ & 48 & $29.00 \pm 1.5$ \\
\hline L-methionine & $14.52 \pm 0.4$ & 72 & $45.14 \pm 7.34$ \\
\hline L-proline & $11.35 \pm 0.31$ & 96 & $47.12 \pm 6.66$ \\
\hline L-lysine & $12.20 \pm 1.1$ & 120 & $39.68 \pm 5.64$ \\
\hline
\end{tabular}


medium $\mathrm{pH}$ negatively influenced the enzyme production. Critical analyses of the L-glutaminase productivity values do suggest that alkaline conditions are more supportive compared to the acidic environment during fermentation by this isolate (Table 1).

\section{The effect of temperature}

Growth temperature is another critical parameter that needs to be controlled. Maximum L-glutaminase production of $40.80 \mathrm{U} / \mathrm{ml}$ was noticed at a temperature of $37^{\circ} \mathrm{C}$. Variation of the temperature on either side of this resulted in decrease in L-glutaminase production. The loss of activity is more at the higher temperature when compared to the lower temperatures (Table 1).

\section{The effect of inoculum size}

The results cited in Table 1 revealed that the production of L-glutaminase by Bacillus sp. DV2-37 increased as the inoculum size increased until it reached its maximum productivity $(45.05 \mathrm{U} / \mathrm{ml})$ at $20 \%$, after that it decreased as the inoculum size increased.

\section{The effect of incubation period}

The maximum enzyme productivity $(47.12 \mathrm{U} / \mathrm{ml})$ by Bacillus sp. DV2-37 was obtained at $96 \mathrm{~h}$ of cultivation period (Table 1). After that, the enzyme production decreased, suggesting its association with growth parameters. It is noteworthy to state that by optimizing the above-mentioned components and culture conditions, the production of L-glutaminase has been increased about ninefold from $5.16 \mathrm{U} / \mathrm{ml}$ of the initial medium composition to $47.12 \mathrm{U} / \mathrm{ml}$ under the final conditions.

\section{Properties of the partially purified enzyme}

The L-glutaminase activity and protein content in each fraction obtained were determined and further used for the estimation of specific activity, yield, and recovery. The specific activity and the purity fold of the enzyme increased gradually with each progression of purification (ammonium sulfate precipitation and dialysis), although the total protein, total activity, and yield reduced relatively (Table 2). Using ammonium sulfate precipitation, the crude enzyme was purified about 1.75 times more and the yield rate was enhanced up to $75.19 \%$ with a specific activity of $53.07 \mathrm{U} / \mathrm{mg}$. The enzyme purity was increased with the dialysis process; the yield and the final specific activity reached $51.15 \%$ and $176.2 \mathrm{U} / \mathrm{mg}$, respectively.

The description and characterization of the enzymes produced by microorganisms are relevant for their possible application in many industries. In the present study, the conditions for enzyme activity reaction were optimized by studying different parameters like $\mathrm{pH}$ of the reaction mixture, temperature, and the effect of $\mathrm{NaCl}$ concentrations. Testing the $\mathrm{pH}$ dependence of enzyme activity revealed that the maximum activity of $\mathrm{L}$-glutaminase was observed at $\mathrm{pH} 7(47.45 \mathrm{U} / \mathrm{ml})$. The $\mathrm{pH}$ stability of the enzyme also showed a similar trend, the enzyme being most stable at pH 7.0 (Fig. 1).

Temperature is a critical factor for the maximum enzyme activity. Upon incubation in different temperatures, the reaction mixture showed an increased rate of enzymatic reaction, from 30 to $40{ }^{\circ} \mathrm{C}$. The enzyme was optimally active $(50.50 \mathrm{U} / \mathrm{ml})$ at a temperature of $40{ }^{\circ} \mathrm{C}$. Incubation above $40{ }^{\circ} \mathrm{C}$ promoted a remarkable inactivation of L-glutaminase from Bacillus sp. DV2-37. Furthermore, L-glutaminase showed thermal stability over a temperature range of $30-50 \mathrm{oC}$ and retained $90 \%$ of its activity at $60^{\circ} \mathrm{C} \mathrm{(Fig.} \mathrm{2).}$

Results presented in Fig. 3 showed that, as $\mathrm{NaCl}$ concentration increased, the activity of the enzyme increased

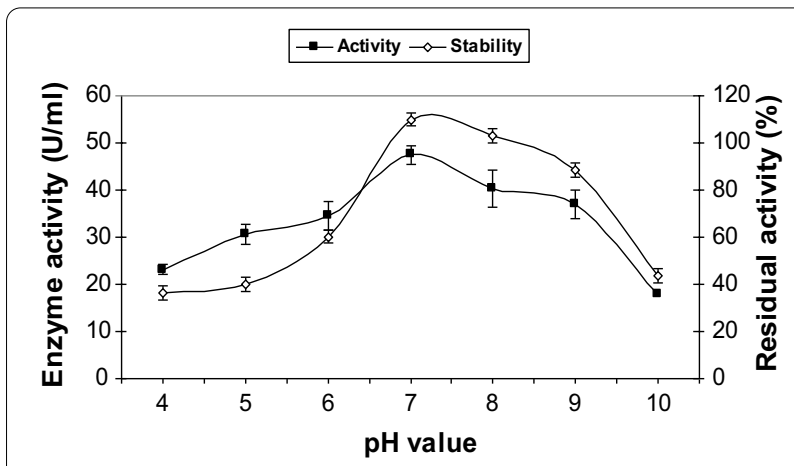

Fig. 1 Activity and stability of L-glutaminase produced by Bacillus sp. DV2-37 as a function of $\mathrm{pH}$ values. Results are means of three independent determinations. Data represent the mean of 3 different readings \pm standard deviation

Table 2 Purification steps of L-glutaminase produced by Bacillus sp. DV2-37

\begin{tabular}{llcccc}
\hline Purification Procedure & Enzyme Activity $(\mathbf{U})$ & Protein $(\mathbf{m g})$ & $\begin{array}{l}\text { Specific activity (U/ } \\
\text { mg) }\end{array}$ & Fold purification & Yield (\%) \\
\hline Cell free extract & 1336 & 565 & 30.23 & 1.0 & 100 \\
Ammonium sulphate & 9871 & 225 & 53.07 & 1.75 & 75.19 \\
Dialysis & 7053 & 58 & 176.2 & 5.8 & 51.15 \\
\hline
\end{tabular}




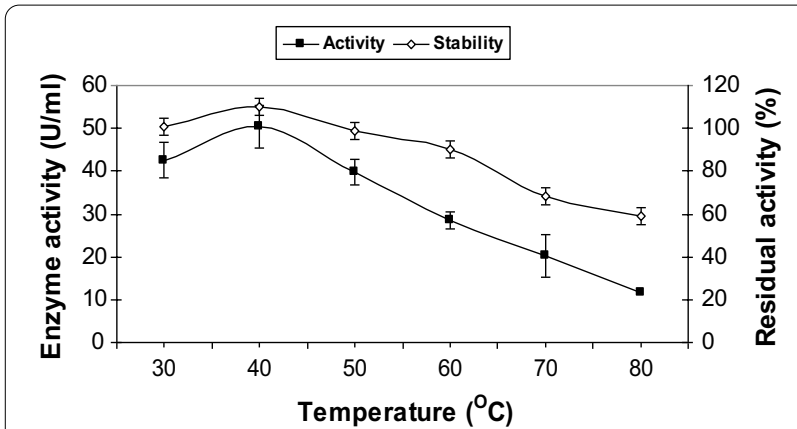

Fig. 2 Activity and stability of L-glutaminase produced by Bacillus sp. DV2-37 as a function of temperature. Results are means of three independent determinations. Data represent the mean of 3 different readings \pm standard deviation

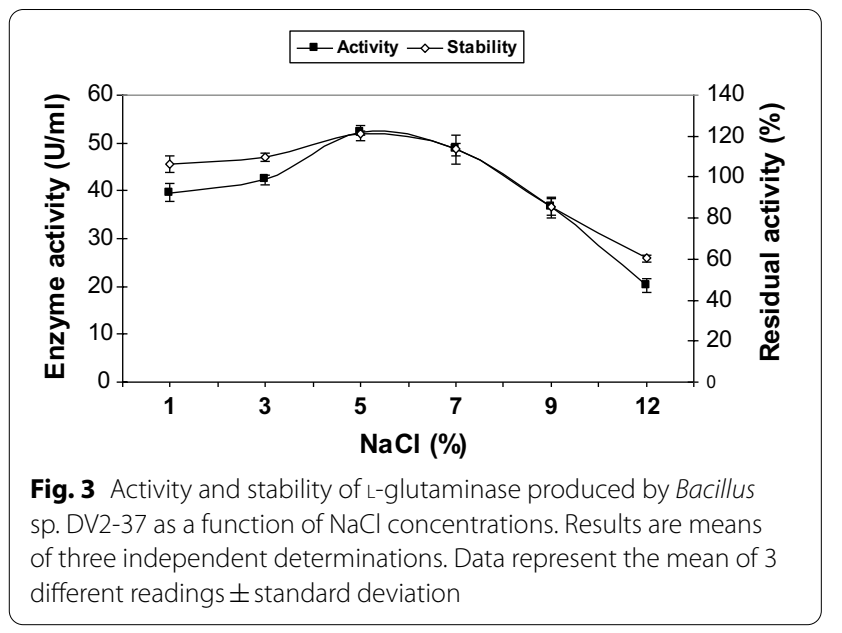

until it reached its maximum activity $(52.11 \mathrm{U} / \mathrm{ml})$ at $5 \%$ $(\mathrm{w} / \mathrm{v}) \mathrm{NaCl}$, after that any increase in $\mathrm{NaCl}$ concentration leads to decrease in enzyme activity. Such results indicated the high salt tolerance of the enzyme. Data presented in Fig. 3 indicated the salt tolerance nature of L-glutaminase from the marine Bacillus sp. DV2-37. It exhibited more than $100 \%$ activity at $1-7 \% \mathrm{NaCl}$ and retained $85.5 \%$ of activity at $9 \% \mathrm{NaCl}$ concentration, whereas glutaminase from non-marine microbes was found to be inactivated at high salt concentrations, limiting their industrial potential.

\section{Anticancer activity}

In the present study, In vitro anticancer activity of L-glutaminase produced by Bacillus sp. DV2-37 was studied against the human breast (MCF-7), hepatocellular (HepG-2), and colon (HCT-116) carcinoma cell lines at different concentration $(50,25,12.5,6.25,3.125$, and $1.56 \mu \mathrm{g} / \mathrm{ml}$ ) by the MTT assay and compared with the standard Doxrubcin. L-glutaminase produced by Bacillus
Table 3 Cytotoxicity activity of L-glutaminase produced by Bacillus sp. DV2-37 against human breast (MCF-7), hepatocellular (HepG2), and colon (HCT-116) carcinoma cells

\begin{tabular}{llll}
\hline $\begin{array}{l}\text { L-glutaminase } \\
\text { concentration }(\boldsymbol{\mu g} / \mathbf{m l})\end{array}$ & \multicolumn{2}{l}{ Viability $(\%)$} \\
\cline { 2 - 4 } & MCF-7 & Hep G-2 & HCT-116 \\
\hline 50 & 8.97 & 6.89 & 9.83 \\
25 & 15.91 & 11.93 & 14.47 \\
12.5 & 24.59 & 20.47 & 23.65 \\
6.25 & 39.42 & 35.29 & 35.54 \\
3.125 & 51.47 & 51.43 & 53.92 \\
1.56 & 74.92 & 82.94 & 68.17 \\
0 & 100 & 100 & 100 \\
\hline
\end{tabular}

Table 4 Inhibition concentrations $\left(I_{50}\right)$ for cytotoxicity activity of L-glutaminase produced by Bacillus sp. DV2-37

\begin{tabular}{lll}
\hline Human carcinoma cells & $\begin{array}{l}\text { L-glutaminase concentration } \\
(\boldsymbol{\mu g} / \mathbf{m l})\end{array}$ & $\begin{array}{l}\text { Doxrubcin } \\
\text { (Standard) }\end{array}$ \\
\hline MCF-7 & 3.5 & 0.426 \\
HepG-2 & 3.4 & 1.2 \\
HCT-116 & 3.8 & 0.469 \\
\hline
\end{tabular}

sp. DV2-37 showed a potent cytotoxic activity of all cell lines in a dose-dependent manner as shown in Table 3. The results showed that MCF-7, HepG-2 and HCT-116 cell proliferation were significantly inhibited by L-glutaminase with $\mathrm{IC}_{50}$ values of $3.5,3.4$, and $3.8 \mu \mathrm{g} / \mathrm{ml}$, respectively (Table 4 ). The produced L-glutaminase exhibited weak toxicity to the normal epithelium retina cell line (RPE-1) with $\mathrm{IC}_{50}$ of $50 \mu \mathrm{g} / \mathrm{ml}$. A blank experiment was conducted containing the same extract concentrations, but heat-inactivated to confirm that this antitumor activity is related to the produced L-glutaminase not to other bacterial proteins. Thus, L-glutaminase produced by Bacillus sp. DV2-37 was found to be a potent cytotoxic agent against MCF-7, HepG-2, and HCT-116 cell lines.

\section{Discussion}

In recent years, marine bacteria play a major role in the fields of health, medicine, and industry. Marine environment harbors a huge pool of novel enzymes that have very unique properties. In this respect, L-glutaminases extracted from marine microorganisms are expected to be characterized by special properties i.e. salt-tolerant and thermo-stable as needed by many industries (Patel et al. 2020).

In the present study, upon screening of the bacterial strains isolated from the marine environment, the strain showed the highest production of L-glutaminase was selected and identified as Bacillus sp. DV2-37. In the 
same line, various halophilic bacterial strains producing L-glutaminase were isolated from marine habitats and identified based on $16 \mathrm{~S}$ rRNAs such as Bacillus subtilis, Bacillus cereus MTCC 1305, Aeromonas veronii, Providencia sp., Acinetobacter calcoaceticus PJB1, and Halomonas (Zolfaghar et al. 2019; Hussein et al. 2020).

The production of pink color zone around the bacterial colony grown on minimal glutamine agar (MGA) medium is an indication of $\mathrm{L}$-glutaminase production (Hymavathi et al. 2009). Earlier method involves the isolation of microorganisms from certain environments by routine isolation procedures and then screened for enzymatic activity. However, the use of selective media and the presence of antibiotics, $\mathrm{NaCl}$, and $\mathrm{pH}$ indicators make MGA medium suitable for direct and selective isolation of L-glutaminase producing marine isolates (Balagurunathan et al. 2010).

Carbon source represents the energy source required for the growth of microorganisms. Carbohydrates and related compounds are considered as the favorable carbon sources for many genera of microbes. The enhanced production of L-glutaminase by incorporation of carbon sources may be attributed to the positive influence of additional carbon sources along with glutamine for enhancing the enzyme biosynthesis (Chitanand and Shete 2012). In the present study, glucose was used as an additional carbon source for yielding the maximum L-glutaminase by Bacillus sp. DV2-37. Similarly, glucose was the best carbon source for glutaminase production by Pseudomonas aurignosa (Al-Zahrani et al. 2020). On the other hand, rhamnose caused the highest L-glutaminase production of the marine bacterial isolate Bacillus subtilis OHEM11 (Orabi et al. 2020).

Nitrogen source has got a profound influence on enzyme production as it is the ultimate precursor for protein biosynthesis. Besides, the nitrogen source can also affect the $\mathrm{pH}$ of the medium, which in turn may influence the activity and stability of the enzyme. The results of the present study revealed that peptone enhanced the enzyme yield. On the contrary, Kiruthika and Nachimuthu (2014) reported that glutaminase production by marine Bacillus subtilis JK-79 was enhanced by using yeast extract. Furthermore, amino acids were reported to be a common growth factor required for the synthesis of enzyme as the major nitrogen source (Cruz Soto et al. 1994); hence, the yield of L-glutaminase produced was varied when the amino acid was changed. In the present study, L-glutamine was found to enhance L-glutaminase synthesis by Bacillus sp. DV2-37. This observation suggests that L-glutamine acts as an inducer for the production of extracellular L-glutaminase enzyme. Similar results were reported by Prakash et al. (2010) who indicated that $\mathrm{L}$-glutamine and $\mathrm{L}$-asparagine resulted in a high yield of L-glutaminase. Moreover, Al-Zahrani et al. (2020) showed that the maximum glutaminase activity by Pseudomonas aurignosa was achieved with glutamine out of various nitrogen sources.

It is well-known that the $\mathrm{pH}$ of the culture medium affects the availability of certain metabolic ions and permeability of bacterial cell membranes, which in turn supports cell growth and enzyme production (Kapoor et al. 2008; Krishna-kumar et al. 2011). In general, the $\mathrm{pH}$ range 6.0 to 8.0 was reported to be the most favorable range for L-glutaminase production by the majority of microbial organisms (Sathish and Prakasham 2010). In the present study, it was noticed that $\mathrm{pH} 7.0$ is optimum for the L-glutaminase production by Bacillus sp. DV2-37. In the same line, Lakshmi and Jaya (2012) stated that the optimum $\mathrm{pH}$ for L-glutaminase production by Aspergillus oryzae NCIM 1212 was at pH7. In addition, the best L-glutaminase production was observed at $\mathrm{pH} 7$ for the forest soil isolated bacterial strain of Bacillus sp. (Nagaraju and Raghu Ram 2018). However, marine Vibrio azureus JK-79 bacterial strain exhibited the maximum glutaminase production at pH 8 (Kiruthika 2013).

Furthermore, growth temperature influenced the microbial metabolism both with respect to the rates of cellular processes run and the enzymatic reactions occur. Sivakumar et al. (2006) reported that any temperature beyond the optimum range is found to have some adverse effects on the metabolic activities of the microorganisms. In the present study, the highest L-glutaminase production by Bacillus sp. DV2-37 was noticed at a temperature of $37{ }^{\circ} \mathrm{C}$. In the same line, Kiruthika (2013) confirmed that the maximum glutaminase activity by Vibrio azureus JK-79 isolated from marine environment was at $37{ }^{\circ} \mathrm{C}$. On the other side, Al-Zahrani et al. (2020) stated that a temperature of $35^{\circ} \mathrm{C}$ is the best one for glutaminase production by Pseuedomonas NS16.

Quantum of initial biomass controls the kinetics of growth and several biological metabolic functions that leading to the overall biomass and extracellular enzymatic production (Wakayama et al. 2005). The highest inoculum concentration caused the reduction of the lag phase, that yielding maximum enzyme productivity (Tobin et al. 2001). In addition, it was reported that maximum enzyme production could be obtained only after a certain incubation time, which allows the culture to grow, after which it decreases. It might be due to the depletion of nutrients in the medium which stressed the bacterial physiology. This reduction of the nutrients resulted in the inactivation of the secretary machinery of the enzymes (Alexandra et al., 2003). In the present study, the maximum enzyme productivity by Bacillus sp. DV2-37 was obtained at $96 \mathrm{~h}$ of incubation period. In the same manner, Krishna-kumar et al. (2011) mentioned that the 
highest production of L-glutaminase by the marine alkalophilic Streptomyces sp. SBU1 was at $96 \mathrm{~h}$ of incubation period. However, maximum L-glutaminase production was achieved at $18 \mathrm{~h}$ of incubation time by marine isolated bacterial strain Bacillus subtilis (Zhang et al., 2019) and at $72 \mathrm{~h}$ of incubation period for Pseudomonas VJ-6 (Jyothi and Shivaeerakumar 2011).

The results of the present study showed that upon optimizing the above- mentioned medium components and culture conditions, L-glutaminase production by Bacillus sp. DV2-37 has been increased from $5.16 \mathrm{U} / \mathrm{ml}$ using the initial medium composition to $47.12 \mathrm{U} / \mathrm{ml}$ (ninefold) under optimum conditions. In the same line, statistical optimization has been reported to enhance the production of L-glutaminase from marine Bacillus subtilis JK-79 up to 3.48 fold when compared with the basal medium (Kiruthika and Murugesan 2020) and up to 2.88 fold under solid state fermentation as compared to the basal wheat bran medium (Kiruthika et al. 2018).

In the present study on the L-glutaminase production of Bacillus sp. DV2-37, the maximum activity was reported at $\mathrm{pH} 7$. As the $\mathrm{pH}$ value diverged from the optimum level, the efficient functioning of the enzyme affected, and this could be ascribed to the decreased saturation of the enzyme with substrate due to a decreased affinity and/or due to the effect of $\mathrm{pH}$ on the stability of the enzyme.

Cancer is one of the most dangerous diseases. It is the second bigger disease of human beings (Rashmi et al. 2012). Although several kinds of treatments are available, enzyme therapy is reported to be the more effective one. Cancer therapy using enzymes relies on the low molecular weight protein, specific in their action and has less or no toxic effects. In addition, the enzymatic approach was reported to be more promising in cancer therapy (Pandian et al. 2014).

Cancer cells, especially, cannot synthesize L-glutamine as they lack the proper functioning glutamine biosynthetic machinery (L-glutamine synthetase) and therefore require large amount of L-glutamine for their rapid growth. These cells depend on the exogenous supply of L-glutamine for their survival and rapid cell division, as it is a primary tool for donation of its nitrogen, which aid in protein, nucleic acid, lipid formation and participate in oxidative metabolism. Furthermore, glutaminase is already present in mitochondria, but it must be at the level that allows sequential and fast degradation of glutamine (Lukey et al. 2013). Hence, the use of L-glutaminase deprives the tumor cells of L-glutamine and causes selective death of L-glutamine dependant tumor cells (Nathiya et al. 2011; Elshafei et al. 2014). The glutamine-deprivation therapy with L-glutaminase that hydrolyzes L-glutamine to L-glutamic acid and ammonia, not only selectively inhibits tumor growth by the blocking of the de novo protein synthesis, but also increase in the superoxide level of oxidative stress that promotes the death of the cancer cells (Mustafa et al. 2020). Thus, it can act as a possible candidate for enzyme therapy. For example, L-glutaminase has been receiving more attention as an antileukemic agent for treatment of acute lymphoblastic leukemia (ALL) and other types of cancer (Orabi et al. 2019).

L-glutaminase enzyme produced by halotolerant isolates can be used for increasing the level of glutamine catabolism and stopping cancer development. In addition, the chemical nature of seawater could provide microbial sources producing enzymes that could have fewer side effects when used in therapeutic applications (Kiruthika and Swathi 2019). Thus, marine bacteria have recently attracted attention for the L-glutaminase production (Zolfaghar et al. 2019). Halomonas meridiana was first reported as an L-glutaminase producer that is used as an anti-colon cancer agent by Mostafa et al. (2021).

In the present study, the produced L-glutaminase by the isolated marine bacterial strain Bacillus sp. DV237 showed potential anticancer activity against all the tested cell lines with $\mathrm{IC}_{50}$ values of $3.5,3.4$ and $3.8 \mu \mathrm{g} /$ $\mathrm{ml}$ for MCF-7, HepG-2, and HCT-116, respectively. Furthermore, it is worth mentioning that the produced L-glutaminase exhibited weak toxicity to the normal epithelium retina cell line (RPE-1) that confirmed that this enzyme possesses great selectivity to cancer cells. In the same trend, many studies investigated the cytotoxicity of L-glutaminase from various microorganisms. For instance, Pandian et al. (2014) reported that purified L-glutaminase by Alcaligenes faecalis KLU102 inhibited the growth of Hela cells with an $\mathrm{IC}_{50}$ value of $12.5 \mu \mathrm{g} / \mathrm{ml}$. Moreover, Nathiya et al. (2012) mentioned that L-glutaminase purified from a bacterium was able to stop a breast carcinoma with $\mathrm{IC}_{50}$ of $256 \mu \mathrm{g} / \mathrm{ml}$. Also, Fifi (2015) indicated that L-glutaminase has a noteworthy efficiency contrary to Hep-G2 cell $\left(\mathrm{IC}_{50}, 6.8 \mu \mathrm{g} /\right.$ $\mathrm{ml}$ ) and a reasonable cytotoxic result against HCT-116 cell $\left(\mathrm{IC}_{50}, 64.7 \mu \mathrm{g} / \mathrm{ml}\right)$. In addition, L-glutaminase produced by Aspergillus oryzae showed significant cytotoxic activity against MCF-7 with $\mathrm{IC}_{50}$ of $283.288 \mathrm{ug} /$ $\mathrm{ml}$ (Sunil et al. 2014). Furthermore, the cytotoxicity effect of L-glutaminase produced by Bacillus subtilis OHEM11 indicated significant safety on Vero cells with high anticancer activity against NFS-60, HepG-2, and MCF-7 cancer cell lines (Orabi et al. 2020). Overall, all these data confirmed that L-glutaminase possesses great selectivity to cancer cell and can display potential application in cancer chemoprevention and chemotherapy. 


\section{Conclusions}

Glutaminase enzyme is an important enzyme in the medical, industrial, and economic aspects. The potential of the isolated Bacillus sp. DV2-37 for L-glutaminase production was analyzed with different process parameters and medium constituents. Maximum production was noticed in a medium supplemented with $1 \%(\mathrm{w} / \mathrm{v})$ glucose as carbon source, $1 \%(\mathrm{w} / \mathrm{v})$ peptone as nitrogen source, $5 \%(\mathrm{w} / \mathrm{v}) \mathrm{NaCl}$, the initial $\mathrm{pH}$ of 7.0 , at $37{ }^{\circ} \mathrm{C}$, using 20\% (v/v) inoculum size after $96 \mathrm{~h}$ of incubation. Under optimal conditions, the glutaminase production improved to $47.12 \mathrm{U} / \mathrm{ml}$. The produced L-glutaminase holds proper features in comparison with others formerly described in the literature. It is active and steady over a widespread range of $\mathrm{pH}$ and temperatures. The produced L-glutaminase showed a pronounced antitumor activity against human breast (MCF-7), hepatocellular (HepG-2), and colon (HCT-116) carcinoma cell lines. Thus, it can play an important role in cancer chemoprevention and chemotherapy.

\section{Acknowledgments}

Not applicable.

\section{Authors' contributions}

The author contributed to the design and implementation of the research, the analysis of the results, and the writing of the manuscript. All authors read and approved the final manuscript.

\section{Funding}

Not applicable.

\section{Availability of data and materials}

Data are available upon request from the author.

\section{Declarations}

Ethical approval and consent to participate

Not applicable.

\section{Consent for publication}

Not applicable.

\section{Competing interests}

The authors declare that they have no competing interests.

Received: 5 November 2021 Accepted: 24 December 2021

Published online: 15 January 2022

\section{References}

Abd-Alla MH, El-Sayed EA, Rasmey AM (2013) Biosynthesis of L-glutaminase by Streptomyces variabilis ASU319 isolated from rhizosphere of Triticum Vulgaris. Univ J Microbiol Res 1(3):27-35

Aishwariyaa LV, Sheeja L, Devi MS (2020) Screening and identification of asparginase and glutaminase producing halophilic bacteria from natural saline habitats. Int J Rec Adv Biotechnol Nanotechnol 3:34-53

Alexandra WZ, Decombaz CG, Affolter M (2003) Functional characterization of salt - and thermo- tolerant glutaminase Enzyme from Lactobacillus rhamnosus. Microbial Technol 32(7):862-867
Altschul SF, Thomas LM, Alejandro AS, Zhang J, Zhang Z, Miller W, Lipman DJ (1997) Gapped BLAST and PSI-BLAST: a new generation of protein database search programs. Nucleic Acid Res 25:83-89

Aly M, Kadi RH, Aldahlawi AM, Alkhatib MH, Wali AN (2017) Production of the antitumor L-glutaminase enzyme from thermotolerant Streptomyces sp. D214 under submerged fermentation conditions. J Exp Biol Agric Sci 5(6):878-885

Al-Zahrani N, Al-Qahtani S, Al-Sehri W (2020) Microbial genetics studies on L-glutaminase producer Psuedomonas NS16 isolated from eye contact lenses. J Am Sci 16(6):34-39

Amobonye A, Singh S, Pillai S (2019) Recent advances in microbial glutaminase production and applications - a concise review. Crit Rev Biotechnol 39(7):944-963

Ardawi MSM, Newsholme EA (1983) Glutamine metabolism in lymphocytes of the 426 rat. Biochem J 212(3):835-842

Balagurunathan R, Radhakrishnan M, Somasundaram S (2010) L-glutaminase producing actinomycetes from marine sediments -selective isolation, semi quantitative assay and characterization of potential strain. Aust J Basic Appl Sci 4:698-705

Binod P, Sindhu R, Madhavan A, Abraham A, Mathew AK, Beevi US (2017) Recent developments in L-glutaminase production and applications_-an overview. Bioresour Technol 245:1766-1774

Chanakya P, Manipati S, Somlanka SR (2010) Process optimisation of L-glutaminase production by Trichoderma koningi under solid state fermentation. IJABPT 1(3):1168-1174

Chitanand MP, Shete HG (2012) Condition optimization and production of extracellular L-glutaminase from pseudomonas fluorescens. Int J Pharm Bio Sci 3(3):155-162

Cruz Soto R, Muhammed SA, Newbold CJ, Stewart CS, Wallace RJ (1994) Influence of peptides, amino acids and urea on microbial activity in sheep receiving grass hay and on the growth of rumen bacteria in vitro. Anim Feed Sci Technol 49:151-161

Elshafei AM, Hassan MM, Ali NH, Abouzeid MA, Mahmoud DA, Elghonemy DH (2014) Purification, kinetic properties and antitumor activity of L-glutaminase from Penicillium brevicompactum NRC 829. Brit Microbiol Res J 41:97-111

Fifi MR (2015) Kinetic properties of Streptomyces canarius L-Glutaminase and its anticancer efficiency. Braz J Microbiol 46:957-968

Hussein AA, Albarazanchi SI, Alshanon AF (2020) Evaluation of anticancer potential for L-glutaminase purified from Bacillus subtilis. Int J Pharm Res 12:293-299

Hymavathi M, Sathish T, Subba Rao CH, Prakasham RS (2009) Enhancement of L-asparaginase production by isolated Bacillus circulans (MTCC 8574) using response surface methodology. Appl Biochem Biotechnol 159:191-198

lyer P, Singhal RS (2010) Glutaminase production using Zygosaccharomyces rouxii NRRL-Y 2547: effect of aeration, agitation regimes and feeding strategies. Chem Eng Technol 33:52-62

Jeong MJ, Hae IL, Sang HH, Chung SC, Jae SS (2010) Partial purification and characterization of glutaminase from Lactobacillus reuteri KCTC3594. J Appl Biochem Biotechnol 162:146-154

Jyothi H, Shivaveerakumar VR (2011) Production of L-glutaminase by Pseudomonas VJ-6. Res J Biotechnol 6(3):42-49

Kapoor M, Nair LM, Kuhad RC (2008) Cost effective xylanase production from free and immobilized Bacillus pumilus strain MK001 and its application in saccharification of Prosopis juliflora. Biochem Eng J 38:88-97

Kiruthika J, Murugesan S (2020) Studies on optimization of L-glutaminase production under submerged fermentation from marine Bacillus subtilis JK-79. Afr J Microbiol Res 14:16-24

Kiruthika J, Nachimuthu S (2014) Isolation and characterization of a novel L-glutaminase producing marine Bacillus subtilis strain JK-79. Asian J Microbiol Biotechnol Environ Sci 16(3):601-610

Kiruthika J, Saraswathy N (2013) Production of L-glutaminase and its optimization from a novel marine isolate Vibrio azureus JK-79. Afr J Biotechnol 23(50):6944-6953

Kiruthika J, Saraswathy N, Murugesan S (2018) Maximizing L-glutaminase production from marine Bacillus subtilis JK-79 under solid state fermentation. Afr J Biotechnol 17(9):288-305

Kiruthika J, Swathi S (2019) Purification and characterization of a novel broad spectrum anti-tumor L-glutaminase enzyme from marine Bacillus subtilis strain JK-79. Afr J Microbiol Res 13:232-244 
Kiruthika JS (2013) Selective isolation and molecular identification of L-glutaminase producing bacteria from marine sediments. R J Biotech 8(8):64-69

Krishna-kumar S, Alexis Rajan R, Ravikumar S (2011) Extracellular production of I-glutaminase by marine alkalophilic Streptomyces sp.-SBU1 isolated from Cape Comorin Coast. Ind J Geo Marine Sci 40(5):717-721

Lakshmi PK, Jaya RK (2012) Production of L-glutaminase by Aspergillus oryzae NCIM 1212 under solid state fermentation using agro residues. J Chem Biol Phy Sci Sec B 1:261-269

Lowry OH, Rosebrough NN, Farr AL, Randall RY (1951) Protein measurement with the Folin Phenol reagent. J Biol Chem 193:265-275

Lukey MJ, Wilson KF, Cerione RA (2013) Therapeutic strategies impacting cancer cell glutamine metabolism. Future Med Chem 5(14):1685-1700

Mostafa YS, Alamri SA, Alfaifi MY, Alrumman SA, Elbehairi SEI, Taha TH, Hashem M (2021) L-glutaminase synthesis by marine Halomonas meridiana isolated from the red sea and its efficiency against colorectal cancer cell lines. Molecules 26:1963

Mustafa G, AL-Juha Asmaa IA (2020) Characterization and antitumor activity study for a therapeutically important L-glutaminase purified from Staphylococcus aureus. Int J Psychosoc Rehabil 24:3029-3037

Nagaraju K, Raghu Ram M (2018) Studies on optimization of L-glutaminase from Bacillus endophyticus RN-7. Int J Pharm Biol Sci 8(3):1146-1153

Nandakumar R, Yoshimune K, Wakayama M, Moriguchi M (2003) Microbial glutaminase: biochemistry, molecular approaches and applications in the food industry. J Mol Catal B Enzymatic 23:87-100

Nathiya K, Nath SS, Angayarkanni J, Palaniswamy M (2012) In vitro cytotoxicity of L-glutaminase against MCF-7 cell lines. Asian J Pharm Clin Res 5:171-173

Nathiya K, Soraj SS, Angayarkanni J, Palaniswamy M (2011) Optimised production of Lglutaminase: a tumor inhibitor from Aspergillus flavus cultured on agroindustrial residues. Afr J Biotechnol 10:13887-13894

Orabi HM, El-Fakharany EM, Abdelkhalek ES, Sidkey NM (2019) L-asparginase and L-glutaminase: sources, production, and applications in medicine and industry. J Microbiol Biotechnol Food Sci 9(2):179-190

Orabi HM, El-Fakharany EM, Abdelkhalek ES, Sidkey NM (2020) Production, optimization, purification, characterization, and anti-cancer application of extracellular L-glutaminase produced from the marine bacterial isolate. Prep Biochem Biotechnol 50(4):408-418

Padma I, Singhal RS (2007) Production of glutaminase (E.C.3.5.1.2) from Zygosaccharomyces rouxii: statistical optimization using response surface methodology. Bioresour Technol 99:4300-4307

Pandian SR, Deepak V, Sivasubramaniam SD, Nellaiah H, Sundar K (2014) Optimization and purification of anticancer enzyme L-glutaminase from Alcaligenes faecalis KLU102. Biologia 69:1644-1651

Patel NY, Baria DM, Arya PS, Rajput KN, Panchal RR, Raval VH (2020) L-glutaminase biosynthesis from marine bacteria. Biosci Biotechnol Res Commun 13(1):67-72

Prakash PJ, Poorani E, Ananthraman P (2010) Effect of media composition on I-glutaminase production from lagoon Vibrio Spp.SFL-2. Int J Biotechnol Biochem 6(5):769-782

Rajeev KS, Chanrdasekaran M (2003) Continuous production of L-glutaminase by an immobilized marine Pseudomonas sp BTMS- 15 in a packed bed reactor. Proc Biochem 38:1431-1436

Rashmi AM, Gopinath SM, Krishan K, Narasimha MTP (2012) optimization of submerged fermentation process for L-glutaminase produced by Pseudomonas aeruginosa BGNAS-5. Int J Lat Res Sci Technol 1(4):2278-5299

Renu N, Yoshimune K, Wakayama M, Moriguchi M (2003) Microbial glutaminase: biochemistry, molecular approaches and applications in the food industry. J Mol Catal 23:87-100

Renugadevi K, Venus AR (2012) Microwave irradiation assisted synthesis of silver nanoparticle using Azadirachta indica leaf extract as a reducing agent and its in vitro evaluation of its antibacterial and anticancer activity. Int J Nanomater Biostruc 2(2):5-10

Rochelle PA, Will JA, Fry JC, Jenkins GJ, Parkes RJ, Turley CM, Weightman AJ (1995). In: Trevors JT, van Elsas JD (eds) Nucleic acids in the environment. Springer, Berlin, pp 219-239

Sabu A (2003) Sources, properties and applications of microbial therapeutic enzymes. Ind J Biotechnol 2:334-341

Sathish T, Prakasham RS (2010) Enrichment of glutaminase production by Bacillus subtilis RSP-GLU in submerged cultivation based on neural network - genetic algorithm approach. J Chem Technol Biotechnol 85(1):50-58
Singh P, Banik RM (2013) Biochemical characterization and antitumor study of L-glutaminase from Bacillus cereus MTCC 1305. Appl Biochem Biotechnol 171(2):522-531

Sivakumar K, Sahu MK, Manivel PR, Kannan L (2006) Optimum conditions for L-glutaminase production by actinomycete strain isolated from estuarine fish Chanos chanos. Ind J Exp Biol 44(3):256-258

Sunil D, Siddalingeshwara KG, Karthic J, Pramod T, Vishwanatha T (2014) Anti-tumour property L-glutaminase on from Aspergillus oryzae through submergrd fermentation. Int J Curr Microbiol Appl Sci 3(3):819-823

Teja DD, Devi VS, Harsha N, Vishala SS, Lakshmi PK (2014) Production of L-glutaminase from marine ecosystems and optimal conditions for maximal production by actinomycetes. Int J Adv Res 2(1):485-491

Tobin P, Robinson M, Olosimbo O, Aboaba K, Maria J, Jozsef B, Bernard M (2001) The effect of inoculum size on the lag phase of Listeria monocytogenes. Int J Food Microbiol 70:163-173

Wakayama M, Yamagata T, Kamemura A, Bootim N, Yano S, Tachiki T, Yoshimune K, Moriguchi M (2005) Characterization of salt-tolerant glutaminase from Stenotrophomonas maltophilia NYW-81 and its application in Japanese soy sauce fermentation. J Ind Microbiol Biotechnol 32(9):383-390

Yulianti T, Chasanah E, Tambunan USF (2012) Screening and characterization of L-glutaminase produced by bacteria isolated from Sangihe Talaud Sea. Squalen 7(3):115-122

Zhang X, Xu Z, Liu S, Qian K, Xu M, Yang T, Xu J, Rao Z (2019) Improving the production of salt-tolerant glutaminase by integrating multiple copies of Mglu into the protease and 16S rDNA genes of Bacillus subtilis 168. Molecules 24(3):592

Zhao J, Lopez AL, Erichsen D, Herek S, Cotter RL, Curthoys NP, Zheng J (2004) Mitochondrial glutaminase enhances extracellular glutamate production in HIV-1-infected macrophages: linkage to HIV-1 associated dementia. J Neurochem 88:169-180

Zolfaghar M, Amoozegar MA, Khajeh K, Babavalian H, Tebyanian H (2019) Isolation and screening of extracellular anticancer enzymes from halophilic and halotolerant bacteria from different saline environments in Iran. Mol Biol Rep 46:3275-3286

\section{Publisher's Note}

Springer Nature remains neutral with regard to jurisdictional claims in published maps and institutional affiliations.

\section{Submit your manuscript to a SpringerOpen ${ }^{\circ}$ journal and benefit from:}

- Convenient online submission

- Rigorous peer review

- Open access: articles freely available online

- High visibility within the field

- Retaining the copyright to your article

Submit your next manuscript at $>$ springeropen.com 